\title{
AC 2008-1711: FLORIDA ENGINEERING TECHNOLOGY FORUM: A VEHICLE FOR CHANGE
}

\section{Marilyn Barger, University of South Florida}

MARILYN BARGER is the Principle Investigator and Executive Director of FLATE, the Florida Regional Center for Manufacturing Education funded by NSF and housed at Hillsborough Community College in Tampa Florida. She earned a B.A. in Chemistry at Agnes Scott College, and both a B.S. in Engineering Science and a Ph.D. in Civil Engineering (Environmental) from the University of South Florida, where her research focused on membrane separations. She has over 20 years of experience in developing curriculum for engineering and engineering technology for elementary, middle, high school and post secondary institutions. She is a registered professional engineer in the State of Florida.

\section{Richard Gilbert, USF}

RICHARD GILBERT is a professor of Chemical Engineering in the College of Engineering at the University of South Florida. He is a co-pi on the FL-ATE Center Grant. He has developed educational materials for ISA (Instrument Society of America), AVS (American Vacuum Society) Science Educator's Workshop, and the National Science Foundation through a grant to develop high school science and math curriculum content. He is currently working with D. L. Jamerson Elementary School to develop curriculum content for its Center for Math and Engineering.

\section{Eric Roe, Hillsborough Community College}

ERIC A. ROE is the Director of FLATE, an NSF Regional Center of Excellence in Manufacturing Education. He received his Ph.D. in Chemical Engineering from the University of South Florida (USF). During his time at USF, he has researched fluidized bed drying, been a consultant to the Citrus Industry, worked on Florida Department of Citrus research projects, and the High School Technology Initiative - funded by NSF. Prior to USF, he was employed as a technologist in Research and Development at Tropicana Products, Inc. with process and product development responsibilities. His research interests are food engineering, fluidized bed drying, and the integration of engineering and education.

\section{Bradley Jenkins, Saint Petersburg College}

BRADLEY JENKINS, is the Director of the Engineering Technology program at St. Petersburg College. He has developed engineering technology related curriculum and course content for the last twenty years and is the director of the Engineering Technology Forum for the State of Florida. He holds a B.S. Degree in Engineering Technology from the College of Engineering at the University of South Florida (USF) and the M. Ed. in Curriculum and Instruction, also from USF. He is the state of Florida course numbering coordinator for the enginering technology curriculum. He is a Co-Principal Investigator for the NSF-ATE regional center for manufacturing education in Florida, FLATE. 


\title{
The Florida Engineering Technology Forum: A Vehicle for Change
}

\begin{abstract}
The Florida Engineering Technology Forum (ET Forum) is becoming an important vehicle to bring together the diverse and geographically dispersed colleges with common issues and challenges. FLATE, the NSF-Advanced Technological Education Program funded Florida Regional Center for Manufacturing Education, utilizes the Forum to strengthen FLATE's Technology Consortium -focused academic programs and mobilize community colleges interested in Advanced Manufacturing and related high tech industries cooperating to realign Florida's Department of Education frameworks for the creation of a new and industry-relevant associate of science degree in Engineering Technology with multiple, viable and accessible upward and downward articulation pathways.

This poster presents the structure and operating characteristics of the Florida Engineering Technology Forum as a model organization for other disciplines and career clusters in Florida as well as technical disciplines in other states. This exportable model brings the community colleges and their university counterparts together with representatives from the Florida Department of Education Workforce Education Division to discuss common issues, best practices, institutional and programmatic news, and to seek solutions that better unify the programs serving students, industry, and academic institutions.
\end{abstract}




\section{Background}

The Florida Community College system is representative of an educational system in which each college is independent, but at the same time, affiliated by a statewide governing board and operating within a geographically defined service area. Although such structure assumes greater institutional significance, it does have its own share of challenges. The state sets a low limit for resources to the community college system and fails to support collaborations among institutions/faculty. Additionally, industry does not recognize the politically set geographic boundaries of school and college districts when looking for its skilled and trained workforce. As a result, individual community colleges fall short of meeting the expectations of this industry. In Florida, this has become a greater issue as the state has transitioned from a rural agricultural economy to a more urbanized, and high tech based economy during the last 30 years and faces the more global issue of an aging technical workforce.

Given the range of challenges, the Florida Engineering Technology Forum (ET Forum) serves as an important vehicle to bring together the diverse and geographically dispersed colleges with common issues and challenges. The Forum was seeded in 1996 as part of a curriculum review of all Engineering Technology programs in Florida. Once that task was completed, the participants agreed to meet periodically to network, exchange ideas, discuss issues, share professional development opportunities and review policy and procedure updates from the Florida Department of Education and, more specifically, the Division of Career and Technical Education.

FLATE was funded in July of 2004 and charged with state-wide curriculum reform for manufacturing and related technologies for community colleges and their partner high schools and universities. From its beginning, FLATE engaged the Florida Department of Education in this undertaking. The FLATE leadership met with the FL DOE Workforce Education representatives with their proposal in early 2005. Traditionally, the DOE is a repository of Curriculum Frameworks that define the skills and competencies of all the workforce education programs in Florida high schools, technical centers, and community colleges. However, they do not initiate change, revise, or add new programs. New programs are submitted for review and acceptance by individual colleges based on local needs and with industry documentation to support the need. FLATE proposed to orchestrate the reform of Manufacturing related community college curriculum across the state in one united effort by working with colleges with related programs and industry partners, to define new and relevant skill sets that would ultimately become the new Curriculum Frameworks for the state. This is a considerable undertaking and a very unique approach to new curriculum development. Rather than having a lot of similar programs spring up when a need arises and each college generating its own program name, CIP code, curriculum frameworks, and course work. The colleges would work together to define a new comprehensive degree. FLATE used the ET Forum as a vehicle to recruit interested colleges, sell the new strategy, and then to meet with the established working group immediately after the ET Forum meetings. This working group met for the $5^{\text {th }}$ time in Pensacola, FL during the $20^{\text {th }}$ Engineering Technology Forum in March 2008.

For the first time since the 1996 project that first brought the engineering technology group together, the ET Forum now has specific goals and objectives. The loosely connected network of 
colleges morphed to a focused and organized vehicle for change in career and technical education in Florida and now is a respected resource for the FL DOE and colleges across the state. The Forum, with FLATE's guidance and leadership, accomplished this by continuing to involve the professionals in the Department of Education, statewide career and technical education professionals, and industry regarding statewide policy and procedural changes that would affect the ET Forum stakeholders and members. Today, the Engineering Technology Forum regularly hosts industry professionals from companies near the host institution; provides professional development for emerging and relevant technologies; participates in DOE statewide reform and change related to ET disciplines; and still provides extensive networking and opportunities for sharing and collaboration amongst colleges.

\section{Meeting Format}

The basic block agenda for the Forum has remained the same over the years. An example agenda (Spring 2008 ET Forum) can be reviewed in Appendix 1. On Thursday morning after a welcome by the host institution and introductions, the group participates in a discussion session on current issues of interest and college updates of all participants. This is an open agenda event with a list of topics ranging from emerging technologies and how to incorporate them into different curriculum, student recruitment, grants, professional development, college policies, new and/or needed equipment, program changes, new courses, and local student trends and interests. Occasionally, one college requests to give a presentation on a project, course, recruitment strategy, etc at his/her college. Although categorized as presentations, they always precipitate discussion and interactive sessions. Lunch is provided by the host institution or by one of its industry partners. The afternoon sessions include a tour of the host college's technical and special facilities and professional development sessions. Thursday evening, there is an informal group dinner at a local restaurant.

The Friday morning session includes a panel of local industry who discusses workforce issues and needs, as well as a number of other topics. This interactive discussion provides the participants an opportunity to compare industry needs across the state and see how they align with their own area. This interaction can help colleges be aware of industry trends and new technologies as well as new mandates that apply to them, and may affect educational institutions. Friday morning also includes an update by a Representative of the Florida Department of Education Career and Technical Education Division; updates from universities and colleges that have programs which community college students can articulate into; and continued round table discussion from Thursday morning. The traditional meeting concludes at noon on Friday with a proposed date and location for the next Forum.

Since 2005, FLATE has offered optional professional development opportunities on Friday afternoon at the conclusion of the ET Forum. FLATE has facilitated a curriculum workshop focused on reform and redevelopment of curriculum at the state level for manufacturing and related engineering technologies. To date, five such curriculum workshops have been held. The state approved Engineering Technology degree with 5 different specializations is the outcome of these workshops. FLATE is continuing the Friday afternoon ET Forum workshops offering sessions on emerging technologies, pedagogy, industry certifications, and new curriculum frameworks. 
With input from the colleges and their local industries as well as the Florida Department of Education, the participants of these workshops have been able to come to consensus on the intellectual and educational content of the new AS/AAS degree. The degree is a one plus one design, with a college certificate embedded in 18 hours of the first year which is defined as the Engineering Technology Core. The ET Core is aligned with the Manufacturers Standards Skills Council (MSSC) Portable Production Technician Certification. The AS/AAS degree currently has 5 specialization tracts (year 2 of the degree plan) which colleges can choose to implement in any number. The frameworks for the new degree program were approved by the FL DOE in May 2007. The group is continuing to discusiions on how to better define and develop the different specializations as well as new specializations. ${ }^{1}$

\section{Forum Impact}

FLATE has used the ET Forum to as its primary vehicle to work with technical faculty throughout the state. FLATE's partnership with the Forum has strengthened it as an organization; helped to define the ET Forum's mission and focused conversation; and certainly increased the visibility in the state of both the ET Forum and the NSF ATE Center (FLATE). The existing organization and its structure had a viable venue for FLATE to build on, without competing for faculty time and resources. The ET Forum has also gained momentum and organizational sophistication such that it can (and does) engage in projects to effect changes in technical curriculum as well as state and local policy affecting CTE (Career and Technical Education) in Florida. FLATE provides and supports an ET Forum website; travel funds for faculty to attend the meetings; serves as a liaison with the DOE; meeting surveys and follow-up; detailed meeting reporting; program research; and most recently, a logo for the ET Forum.

Through the ET Forum, FLATE is able to engage interested faculty and administrators from across the state in developing the new curriculum framework for the Engineering Technology Degree. Rather than one college developing a new program in isolation, the group effort has yielded this comprehensive and flexible curriculum for the state that articulates from related high school academies and technical programs and into several 4 year degree programs seamlessly across the state. FLATE is continuing to lead the ET Forum in its participation in more statewide initiatives including Perkins IV implementation and a long term plan to consolidate the duplicative courses with different prefixes and numbers that have come into the state's common course numbering system.

\section{ET Forum Benefits}

The Forum provides many benefits to the attendees, as noted in the surveys and comments from the participants as well as its regular and stable attendance. The low cost, relatively informal meetings have seeded a close network of faculty and administrators focused on the everyday workings and issues of related technical programs. It has resulted in a number of shared projects and grants; mentoring for new and/or evolving programs; and a strong partnership of institutions

that have discovered that they can share the same mission and goals and express their differences within a spirit of cooperation, not competition. The Forum as an organization has moved from being a strictly reactive organization to being proactive, especially with respect to policy and 
procedures changes in the state. The Forum also regularly provides input to the FL DOE and various career and technical education organizations in Florida.

\section{Concluding Remarks}

Over the last 11 years, the 19 ET Forums have met at 15 of the 23 community colleges in the state. There is no charge for the meeting and the host college or college partner provides two breakfasts and one lunch, a meeting room, arranges for hotel rooms nearby, and chooses a local site for dinner. The host is given some time to highlight its programs, campus, and special events. Brad Jenkins, Director of Engineering Technology at St. Petersburg College, currently serves as the permanent Co-Chair of each Forum, and shares meeting organizational duties with a representative of the host college. They sends out meeting notices, agendas and minutes, maintains the contact list, as well as facilitates the meeting itself. Between 30 and 40 program managers, deans and faculty from technical disciplines including Information Technology, Manufacturing Technology, Engineering Technology, Electronics, as well as Drafting and Design, attend each Forum. Each participant is responsible for his or her own travel. The most recent ET Forum was held March 6-7, 2008 at Pensacola Junior College (PJC), which serves Escambia and Santa Rosa Counties in the state's panhandle. The fall 2008 Forum will be hosted by Seminole Community College in Central Florida. For more information on the ET Forums visit: www.fl-ate.org/partners/et_forum.htm

\section{Meetings of the Florida Engineering Technology Forum}

\begin{tabular}{|c|l|l|}
\hline 1 & S 1996 & University of Central Florida \\
\hline 2 & S 1997 & Seminole Community College \\
\hline 3 & F 1997 & Gulf Coast Community College \\
\hline 4 & S 1998 & Manatee Community College \\
\hline 5 & F 1998 & Indian River Community College \\
\hline 6 & S 1999 & Valencia Community College \\
\hline & F 1999 & No meeting \\
\hline 7 & S 2000 & Daytona Beach Community College \\
\hline & F 2000 & No meeting \\
\hline 8 & S 2001 & Miami Dade Community College \\
\hline & F 2001 & No meeting \\
\hline 9 & S 2002 & Valencia Community College \\
\hline 10 & F 2002 & St. Petersburg College \\
\hline 11 & S 2003 & Gulf Coast Community College \\
\hline 12 & F 2003 & Florida Community College at Jacksonville \\
\hline 13 & S 2004 & Palm Beach Community College \\
\hline & F 2004 & No meeting \\
\hline 14 & S 2005 & Daytona Beach Community College \\
\hline 15 & F 2005 & Hillsborough Community College (Brandon) \\
\hline 16 & S 2006 & Indian River Community College \\
\hline 17 & F 2006 & Valencia Community College \\
\hline 18 & S 2007 & Central Florida Community College \\
\hline
\end{tabular}




\begin{tabular}{|l|l|l|}
\hline 19 & F 2007 & Brevard Community College (Palm Bay) \\
\hline 20 & S 2008 & Pensacola Junior College \\
\hline 21 & F 2008 & Seminole Community College \\
\hline
\end{tabular}

\section{Bibliography}

1. Barger, M; Roe, E; Jenkins, B; Gilbert, R. "Engineering Technology Curriculum Reform in Florida", Proceedings ASEE Annual Convention, 2007 Honolulu, HI

APPENDIX A - Typical Engineering Technology Forum Agenda

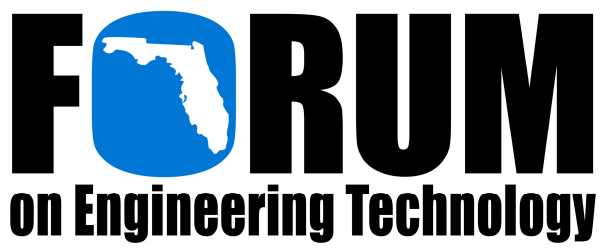

\section{THURSDAY, March 6, 2008}

8:30 AM - Continental Breakfast

9:00 AM Welcome - Pensacola Junior College; Introductions and Forum Overview

\section{Brad Jenkins, SPC and Bob Pierce, PJC}

9:15 AM Issues Forum - Industry challenges and training opportunities; Industrial Partnerships, Enhanced Training, Encumbered Workers-Are they our best bet, CO-OP opportunities, Employment opportunities, Experiential Learning Programs (ELP), Jobs are still available; High School Initiatives, Recruitment of students - How do we recruit?, How do we get them interested in Technology?, High School Articulations, Hugh users of electronic devices, Career Academy -Career Paths, will they work?

10:30 AM - Enrollment and Recruitment Strategies

Terry Bartel, Fox Valley Technical College

11:15 AM - Engineering Technology and Electronic Programs and courses (Successful Program Initiatives, Alternative Delivery - Hybrid, Blended, On-Line, Innovative Classroom Practice and Teaching Methods, New subjects, new technology, Expansion of Topics, modification of subject matter Specific Electronics programs (Consumer electronics, Security Electronics Systems, New Lab Techniques, Virtual lab settings, Electronic national certifications - Are they beneficial?)

12:15 PM - Lunch and Learning Labs, Inc

1:30 PM - Tour of the Facilities

Mechanical Design \& Fabrication Demonstration

Mike Cannon, PJC 
2:30 PM - Learning Objects for Engineering Technology

Terry Bartelt, NSF Sponsored Project, Fox Valley Technical College

4:00 PM State Course Numbering System (SCNS) - Update Brad Jenkins, SPC EET, EST, CET, and EEV courses

6:00 PM Dinner at McGuire's Irish Pub

FRIDAY March 7, 2008

8:00 AM - Continental Breakfast

8:30 AM - Round Table Discussion with the Pensacola Advisory Committee

9:45 AM - Issues Forum; Continued discussion from Thursday; University Connections/Articulations; other topics 10:45 AM - Break

11:00 AM -Update on Workforce Education

Eric Owens, State Supervisor State of Florida Industrial Education

11:45 AM - Engineering Technology Forum Wrap-Up

Noon - Adjournment and Final Announcements

Fall 2008 Forum - Seminole Community College

\section{FLATE MANUFACTURING/ENGINEERING TECHNOLOGY WORKSHOP}

12:00 Noon - 3:30 PM. Professional Development and Training Workshop. This workshop will cover the revised MSSC Standards and the mapping process. This workshop will be applying these new Manufacturing Skills Standards Council's (MSSC) standards to the competencies in the six Engineering Technology Core courses. Everyone interested is invited to attend and participate in the process. FL-ATE will pay a stipend of $\$ 75$ to all participants. A complimentary lunch will be served at the beginning of the meeting.

Sponsored by the FLATE Manufacturing Center Marilyn Barger, Executive Director

In cooperation with the Florida Department of Education, Workforce Education (Contact Marilyn Barger, (813) 259-6578, mbarger@hccfl.edu, or Brad Jenkins, (727) 341-4378, jenkinsb@spcollege.edu for registration to this workshop)

ENGINEERING TECHNOLOGY FORUM CONTACTS

Brad Jenkins, Co-Chair Robert Pierce, Co-Chair

St. Petersburg College Pensacola Junior College 